imagination. I spend some of my time counselling students who suffer from unrelieved feelings of guilt - often inculcated by the Churches - I have no desire to make anyone feel guilty. Guilt is a redundant emotion.

Christians in the animal movement have a unique opportunity. St. Paul speaks of the creation as in a state of childbirth awaiting a new age. Together we have vision of a new age, a new world. A world at peace, a world in which we have begun to make peace with creation. A world in which the Love of God is claimed and championed and through whose Spirit new world possibilities are constantly being opened up for us. What a difference it would make if Christians began to practice the Gospel of Love they preach. At the very least what we need to do is to encourage and inspire people to live free of injury to animals. All of us, in addition to whatever social vision we may have, need a programme of personal disengagement from injury to animal life.

Let me be personal for a moment. I haven't always been an advocate of animal rights. By no means. When I was young I used to enjoy controlling animals and making them captive. I used to enjoy fishing. I used to eat animals. I had no problems about eating veal. My entry into the animal rights movement coincided with my entry into a slaughterhouse when I was 16 years old. The questions that it raised in my mind have been with me ever since. Recently, during my speaking tour of the United States, I visited another slaughterhouse in the State of Mašsachusetts. As I stood watching a young pig being slaughtered -'stuck' as they say in the US -

I asked myself this question: "What has changed in 26 years when animals are still treated as things?" And soon I had my answer: the owner of the slaughterhouse, despite the fact that I had asked permission in the usual way, turfed me out. I'm not used to being turfed out of places. It was a new experience and a valuable one. For I learnt this one thing: What is changing is that many people, even those intensely involved in the exploitation of animals, many people are not so sure as they once were that what they are doing is right. People are beginning to have a conscience even in the most unlikely places.

When I became intellectually convinced of the case for animal rights, I first thought it one of those important but comparatively minor questions in Christian ethics. I don't think that today. On the contrary, I think the question of how we treat animals one of the BIG questions confronting all humanity: if God loves and cares for this world, shall we learn to live at peace with one another and with this world? In short: Are we to hate the world or are we to love it? "We must love one another or die," wrote W.H. Auden. The truth we also have to learn is this: We must love the world, or we shall perish with it.

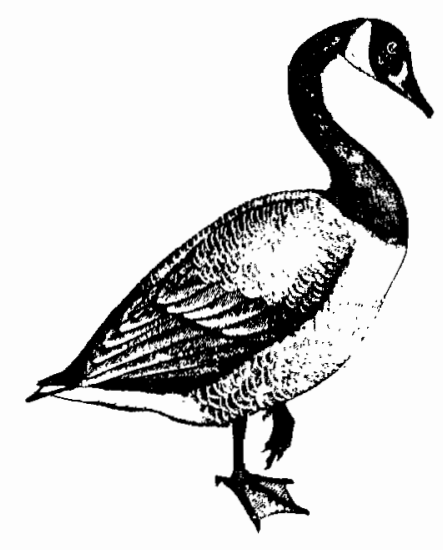

NOYEMBER

\section{OF THE CANADA GEESE}

\author{
Beautiful children \\ of the Northern Lights. \\ Perhaps untamed, runaway stars. \\ Seasons of black and white wonder \\ against the sky. \\ Nobility of spirit; \\ each one faithful \\ to the love of his life. \\ Autumn sun rises \\ on another bewildered dreamer \\ falling in a sudden profanity \\ of gunshot.
}

- Kathleen Malley 